\title{
Do You Realize Two Basic Questions in Genetics?
}

\author{
Muying Zhou \\ The Central Hospital of Shandong Feicheng Coal-Mining Group Corporation, Feicheng, China \\ Email: fckzmy@sina.com, fckzmy@aliyun.com
}

How to cite this paper: Zhou, M.Y. (2018) Do You Realize Two Basic Questions in Genetics? Open Access Library Journal, 5: e4396.

https://doi.org/10.4236/oalib.1104396

Received: February 2, 2018

Accepted: February 24, 2018

Published: February 27, 2018

Copyright (๑) 2018 by author and Open Access Library Inc.

This work is licensed under the Creative Commons Attribution International License (CC BY 4.0).

http://creativecommons.org/licenses/by/4.0/

(c) (i) Open Access

\begin{abstract}
There are two basic questions in genetics. The "first question" inquires about the germplasm that is capable of producing an individual. It asks "Who produces the individual?" Preformation, Darwin's Pangenesis, and Weisman's Germ-plasm theories are all attempts to answer the "first question". The "second question" usually arises in sexually reproducing species. Because there are two parents ( $\mathrm{dad}$ and $\mathrm{mom}$ ) that form the producer (germplasm), one question arises: which pattern (dad or mom) appears in the offspring? It asks "What thing stimulates dad (or mom) to produce offspring having their own pattern?" As in his experiments, Mendel assumed that "the tall (short) variety contains something that makes the plants tall (short)". "Blending inheritance", which has been popular in history, is an attempt to answer the "second question". In short, the "first question" is a matter of the germplasm; and the "second question" is a matter of the template. Mendel's experiments are typical "second question" experiments. Therefore, the gene found by Mendel is the template that promotes the formation of the individual (traits) rather than the producer. However, the basis of genetics should be the germplasm (producer) rather than the template.
\end{abstract}

\section{Subject Areas}

Biochemistry, Genetics, Molecular Biology

\section{Keywords}

Hereditary, Germplasm, Gene, Template, Genetics

\section{Introduction}

In 2010 J.C. Venter et al. reported that they had created a man-made genome and had used it to make "synthetic life" [1]. This suggested that the genome 
(genes) is the producer of an individual (cell), which is consistent with the modern genetics consensus: "germplasm: the hereditary material of the germ cells: genes" [2].

However, Dr. Gerald Joyce, an internationally renowned life scientist at the Scripps Institute in California, responded in the New York Times to people's alarm in thinking that the synthetic cell was a new life form or an artificial cell, said: "Of course, that's not right-its ancestor is a biological life form." The New York Times continued: "Dr. Venter copied the DNA from one species of bacteria and inserted it into another. The second bacteria made all the proteins and organelles in the so-called 'synthetic cell..." [3]. Such a proposition means that the genome (genes) is not the producer of the individual (cell included).

The antagonism between the two views above exposes a crisis in modern genetics.

In fact, when genes were proven to be DNA, the crisis emerges. In 1944, Avery et al. confirmed that genes are made of DNA, and said: "DNA is capable of stimulating unencapsulated $\mathrm{R}$ variants of Pneumococcus Type II to produce a capsular polysaccharide" [4]. Here it is initially revealed that the gene (DNA) is the stimulator for producing a specific trait rather than the producer of this trait.

Today molecular biology provides full and comprehensive evidence for the above facts. On the one hand, it is impossible that DNA serves as the producer of the individual, because it consumes no energy, does no work, and is unable to establish 3',5'-phosphodiester bonds or peptide bonds in the process of individual formation. On the other hand, DNA was proven to be a template; it is a direct template for RNA, which is the template for protein. Therefore, the gene is the source of the template for producing individuals and their traits.

The real world is equally grim. It has yet to give modern geneticists an example where a genome (genes) has produced an individual (including cell).

However, the entire genetics community remains stubbornly mired in an anti-scientific quagmire. If DNA produces an individual (or trait) then it would become a perpetual motion machine: without consuming energy or doing work, DNA could create chemical energy that turns nucleotides, amino acids and other raw materials into products, such as individuals and their traits. This is contrary to the law of energy conservation and is anti-scientific.

The reason that the genetics community is being willfully anti-scientific is that they do not know where they are wrong. Thus, we have to realize the two basic questions in genetics.

\section{Two Basic Questions in Genetics}

\subsection{First Question}

The "first question" is to inquire about the producer i.e. the hereditary material of the germ cells: germplasm that is able to give rise to the individual. It asks "What material (or who) produces the individual?" or it asks the germplasm

"what (who) are you?" Production is the basis of heredity. Without production, 
no egg could become an individual (such as a dog, fish, and tree), and no phenotypic traits could pass from parents to their offspring. Thus, in the world of life there would be no things like heredity. The Preformation theory, Darwin's Pangenesis, and Weisman's Germ-plasm theory are all attempts to answer the "first question". The Preformation theory states that the producer is the miniature, Darwin's Pangenesis states that the producer is gemmules, and Germ-plasm theory states that the producer is germ-plasm. Modern genetics believes that genes are the producer, or "germplasm: the hereditary material of the germ cells: genes" [2]. However, genes (DNA) have no producing capacity, therefore, they cannot be the producer. Thus, to date, no one has provided a specific or correct answer to the "first question".

\subsection{Second Question}

The "second question" usually appears in sexually reproducing species. Because there are two parents (dad and mom), for the producer (germplasm) a new question arises: which specification pattern (dad or mum) appears in the produced offspring? It asks the germplasm "what thing stimulates you to produce an individual having dad's (or mum's) pattern or a compromise pattern?" In daily life, the "second question" leads people would to ask questions such as, "Why is Tom's oldest son tall like Tom, while the younger son is short like Tom's wife?" or “Why is Tom's son's (or daughter's) nose similar to Tom's nose but ears are similar to those of Tom's wife?" or "Why do the noses of the Habsburg family seem to be produced from only one template?". "Blending inheritance", which has been popular in history, is an attempt to answer the "second question".

Obviously, the above two basic questions are different. In short, the "first question" is a matter of germplasm; while the "second question" is a matter of pattern, or we can adopt the term "template", which is widely used today.

The biggest difference between a germplasm and a template is that the germplasm is the producer, and the template is the information carrier of the specifications of a product. The information on the template may be expressed in verbal, digital, geometrical, physical, or chemical forms, and only under the guidance of the template can the producer generate a product of a particular specification.

Because the miniature in the preformation theory could develop into an individual, it is also imagined for germplasm; this is where the miniature differs from the template gene. The template itself is not capable of producing. That is to say, the germplasm outside the template must also have the producing force to carry out production to create the individual, just as an aircraft factory must have a production line in addition to the aircraft blueprint to create the aircraft.

\section{Mendel's Experiments}

The title of Mendel's paper, "Experiments on Plant Hybridization" [5], itself in- 
dicates that Mendel's experiments addressed the "second question" in genetics. For example, in one of his experiments "he crossed a tall variety of edible pea to a short variety. The offspring, or hybrids, F1, were all tall. These were allowed to self-fertilize. Their offspring were tall and short in the ratio of three tall to one short" [6]. It is impossible to carry out such experiments in the vast asexually reproductive species.

However, similar questions are common in modern machine manufacturing. For example, we can ask Boeing "Why do you produce some planes that are long and some that are short? Why is the first batch all long? Why is the last batch both long and short at a ratio of 30 long to 10 short?"

Are such questions asking what (who) is the producer of the plane? Of course not. If Boeing answers, "Because we have a plane factory", it would certainly be suspected that the spokesperson's brain was not functioning. Here, we are not inquiring about the producer; on the contrary, it is the producer (Boeing, plane factory) who should answer our question. The full text of the questioning should be as follows: "Based on the fact that Boeing produces planes, we know that you can produce planes. However, we wonder why do you produce some planes that are long and some that are short? Why is the first batch all long? Why is the last batch both long and short at a ratio of 30 long to 10 short?"

It is common today to correctly answer such questions, as follows: "Because we (the producer of planes) have plane blueprints controlling the specifications of the product (plane). When producing long planes, we have a blueprint controlling or making the product (plane) long, and when producing short planes, we have a blueprint controlling or making the product (plane) short." This common knowledge is a great inspiration for understanding the "second question" in genetics. Thus, we may wonder if the pea plant producer (germplasm) also contains something that controls product specifications.

We find that Mendel thought exactly this, based on the following: "if the tall variety contains in its germ cells something that makes the plants tall, and if the short variety carries something in its germ cells that makes the plants short" [6]. The "something" here is the stimulator for producing tall (short) plants rather than the producer of tall (short) plants. This is exactly the same as what the Avery et al. has revealed. The gene (DNA) is the stimulator of a specific trait (a capsular polysaccharide) rather than the producer of this trait (a capsular polysaccharide). This proves that the subject matter of Mendel's experiments is the template rather than the producer. This is the first time people have had such a vision, and this idea completely changes the previous thinking on "Blending inheritance". It was this idea that ultimately led Mendel to discover the "something" that controls the specification of the individual (traits), which is the gene.

\section{Mendel and Modern Genetics}

Mendel did not propose a hereditary theory to replace Darwin's pangenesis or Weisman's Germ-plasm theory. In his paper [5] Mendel only reported on a he- 
reditary element (genes) and its hereditary laws; he never said that this element (genes) was the only element of heredity. Thus, Mendel never said (or implied) that genes are the only constituent to form the germplasm able to produce the individual. Therefore, the so-called scientific consensus that has evolved over the past 100 years, including "Genetics is the science of genes", "Mendel is the father of genetics" and "germplasm: the hereditary material of the germ cells: genes" (visible in encyclopedias and textbooks), is entirely a human creation after rediscovering Mendel's work and has nothing to do with Mendel himself.

The fact that modern genetics has prevailed for 100 of years shows that people have never realized the two basic questions in genetics, and thus, they confused the questions, mistook genes for the germplasm, and get stuck in the mire.

\section{Conclusions}

In genetics there are two basic questions: the "first question" is a matter of the germplasm and the "second question" is a matter of the template.

Mendel experiments were typical experiments that addressed and solved the "second question". Through experiments the gene discovered by Mendel is a hereditary (template) element controlling the specifications of an individual (traits) rather than the germplasm (or the hereditary material of the germ cells).

True modern genetics has not yet been established, because its foothold, the germplasm (the hereditary material of the germ cells), has not yet been finalized.

\section{Acknowledgements}

We thank Lesley Benyon, PhD, from Liwen Bianji, Edanz Group China (http://www.liwenbianji.cn/ac), for editing the English text of a draft of this manuscript.

\section{References}

[1] Gibson, D.G., Grass, J.I., Lartigue, C., Noskov, V.N., Chuang, R.Y., Algire, M.A., et al. (2010) Creation of a Bacterial Cell Controlled by a Chemically Synthesized Genome. Science, 329, 52-56.

[2] Germplasm. http://www.britannica.com http://www.merriam-webster.com/dictionary/germ\%20plasm

[3] Wade, N. (2010) Researchers Say They Created a "Synthetic Cell". New York Times, 20 May 2010.

[4] Avery, O.T., MacLeod, C.M. and McCarty, M. (1944) Studies on the Chemical Nature of the Substance Inducing Transformation of Pneumococcal Types. Journal Experiment Medicine, 79, 137-158.

[5] Mendel, J.G. (1865) Versuche über Pflanzenhybriden. Verhandlungen des naturforschenden Vereines in Brünn, Bd. IV für das Jahr.

[6] Morgan, T.H. (1928) The Theory of the Gene. Yale University Press, New Haven, 2. 